\title{
Maze test: an instrument to evaluate age-related cognitive and motor changes in humans
}

\author{
Damião Ernane de Souza", Débora Carvalho de Oliveira", Tania Fernandes Campos"**
}

\begin{abstract}
Changes in cognitive and motor ability performance due to advancing age can compromise daily activities. It is important to determine if the maze test can be sensitive to the cognitive or motor alterations of normal ageing. This, the aim of the study was to verify age-related differences in executive function, learning and short-time memory by means of the maze test. Participated 80 healthy individuals, 40 young people (22 \pm 2 years) and 40 elderly individuals (67 \pm 5 years), underwent a health and cognitive evaluation (Mini Mental State Examination). Participants were timed solving thirty mazes, and another 15 minutes later. The data were analyzed by ANOVA and multiple linear regression. The elderly subjects took longer to solve the mazes, suggesting difficulties in executive function; learning took place in the first trials and a short-time memory deficit occurred. A correlation was observed between the cognitive and
\end{abstract}

maze test $(r=-0.320 ; p=0.003)$. Age was the only predictive factor of performance. It is suggested that the maze test may contribute to the monitoring of premature cognitive and motor alterations in the elderly.

Keywords: Executive function. Learning. Memory. Cognition. Elderly.

\section{Introduction}

The effects of aging on cognitive and motor functions have been approached in different studies. It is recognized that aging is accompanied by changes in velocity or in the manner of processing information in the brain (SALTHOUSE, 2000). Studies on cognitive function have shown, through an assortment of atten-

* Doctor in Public Health / Epidemiology for Public Health Institute, Federal University of Bahia - ISC/UFBA, Planning Analyst, Infrastructure and Management in Geographic Information and Statistics Brazilian Institute of Geography and Statistics - IBGE, Natal/ RN, Brazil.

** Master of Physiotherapy, Professor of Neurological Physiotherapy in the Faculty of Health Sciences of Trairi, Department of Physiotherapy, Santa Cruz/ RN, Brazil

*** Doctor in Psychobiology, Professor of Neurological Physiotherapy at the Federal University of Rio Grande do Norte, Department of Physiotherapy, Center for Health Sciences, Laboratory of Chronobiology, Laboratory of Movement and Health, Natal/ RN, Brazil. Corresponding Author: Universidade Federal do Rio Grande do Norte, Departamento de Fisioterapia, Avenida Senador Salgado Filho, 3000, CEP: 59066-800, Natal/RN, Brazil. E-mail: taniacampos@ufrnet.br

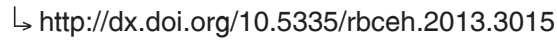


tion, executive function and memory tasks (MILHAN et al., 2001; WECKER et al., 2000; DENNIS; DASELAAR; CABEZA, 2007) that the elderly display deficits in reaction time and response accuracy. Changes in cognitive ability performance due to advancing age can compromise daily activities and consequently, quality of life (LOW; MOLZAHN, 2007) and even life expectancy. One study found that nondemented elderly showing rapid decline in the measures of visuospatial functions, language, and basic and instrumental activities of daily living were around twice as likely to die than nondemented elderly presenting with no or slower decline (SCHUPF et al., 2005).

With respect to motor skill performance, literature data indicate age-dependent differences in motor learning. In an earlier study, motor acquisition in a group of young individuals was significantly faster than in the older group (PERROT; BERTSCH, 2007). An interesting aspect is that motor execution for older adults was dependent on cognitive control, suggesting that cognitive capacity is a determinant of motor slowness in the elderly. Nevertheless, recent results have shown that ageing is accompanied by the functional dysregulation of motor cortex excitability during sensorimotor processing. This deficit becomes progressively evident with increasingly complex motor tasks (YORDANOVA et al., 2004). Another study found motor acquisition deficit in older adults; however, they exhibit normal transfer of learning, indicating that motor acquisition and transfer are distinct processes, affected differently by age (SEIDLER, 2007). All the results found to date show that the causes of reduced motor learning are multifactorial. It is therefore, important to explain age-related mechanisms and processes of decline.

Few studies have focused on the development of instruments that analyze motor behavior and its relation with cognitive functions. It is difficult to elaborate an experimental test, which must be based on the need to identify and combine the elements of motor behavior and cognition present in a same task. It is essential to promote the use of standardized and simplified assessments that contribute to effect monitoring of early cognitive-motor alterations in the elderly, in such a way that interventions can be planned to minimize the repercussions in the activities of daily living in these individuals. The tests must be able to identify changes due to age in the various processes involved in recovery, organization, execution and motor learning. The investigations must consider the mental operations that occur between stimulus and response, thereby evaluating the cognitive activities that precede motor action.

Maze tests have been used in research and clinical practice to enable the evaluation of different cognitive and motor processes (OTT et al., 2003; SOUZA; FRANÇA; CAMPOS, 2006; KIRSCH et al., 2006). The task of solving a maze involves attention and perception during the analysis of the visuospatial stimulus, executive function at the moment of planning, organization and motor action, as well as when deciding on the correct solution path, especially when 
encountering a fork in the path. The response is planned based on decisions made, trial and error, and performance improves through various trials until it is stabilized and the learning process is understood; the information is then stored in memory (KIRSCH et al., 2006). Studies using functional magnetic resonance imaging (fMRI) have shown evidence of an activation pattern of numerous cerebral structures linked to different cognitive and motor processes. The decision to take alternative paths inside the maze (executive function) involved the activation of the pre-frontal cortex. During the processing of visual information related to the analysis of the spatial characteristics of the stimulus, the occipital and parietal regions were activated. Furthermore, activation occurred in regions associated with planning and motor execution, such as the basal ganglia, supplementary motor areas and premotor and primary motor areas (KIRSCH et al., 2006).

In a previous study, young healthy male undergraduates were tested using a maze developed and supplied by the Mathematics Department of the Federal University of Rio Grande do Sul through the site www2.mat.ufrgs.br/edumatec/ softwares/soft_recreativos.php\#winarc. This study confirmed that the maze test can contribute with the evaluation of the acquisition process of a motor ability since it has a specific goal and allows for the manipulation of different levels of complexity, stimulating the use of cognitive strategy to solve the test(KIRSCH et al., 2006). The need arose for a study to verify if the maze test could determine age-related differences in executive function, learning and short-time memory and if these could be associated with a cognitive screening test in order to consider their possible use in the diagnostic evaluation of cognitive or motor alterations of normal or pathological ageing.

\section{Methods}

Subjects

The study comprised 80 healthy individuals allocated to two groups: 40 healthy young undergraduates and 40 elderly individuals enrolled at the Elderly Care Center (CREAI), with 20 men and 20 women in each group. The age range of the young subjects was between 18 and 25 years and of the elderly between 60 and 77 years. The inclusion criteria for the students and healthy elderly were the following: individuals with no evident signs or diagnosis of any general health disorder, who were functionally independent and capable of understanding and performing the study tests. The exclusion criteria: left side laterality, presence of chronic diseases, musculoskeletal alterations in the upper right limb, serious functional incapacity, use of medications acting on the nervous system that could interfere in task performance and illiterate individuals. Simple random probability sampling was used. 


\section{Procedures}

The study was approved by institutional Research Ethics Committee. Participants were informed of the procedures of the investigation and signed the terms of agreement. In order to evaluate the general health of the subjects and include those without pathologies the CIRS (Cumulative Illness Rating Scale) scale was applied. This scale provides information on six organic systems: cardiovascular/respiratory, gastrointestinal, genitourinary, musculoskeletal and tegumentary, neuropsychological and general/endocrine system, on a severity scale of 0 to 4 points, followed by an evaluation of manual dominance (PARMELEE et al., 1995). The Beck Depression Inventory was used to exclude cases of depression (BECK; STEER; GARBIN, 1988).

The Mini Mental State Examination (MMSE) (FOLSTEIN; FOLSTEIN; MCHUGH, 1975) was used in cognitive evaluation, and to perform the maze test 30 identical mazes were printed on a sheet of paper measuring $7 \times 7$ centimeters were initially used. These were solved one at a time at the sound of a bell and the total execution time was recorded. After an interval of 15 minutes, an additional maze was solved, for a total of 31 mazes. Each maze had only one entrance to the left and an exit to the right, enabling six different solution paths, only one of which was the shortest. A high number of trials were projected in order to ensure conditions for observing behavior stabilization.

We considered that the planning and processing of information to find the shortest path to solving the maze (executive function) could be evaluated by the time of execution. The learning process would be determined by the evaluation of stabilized performance (execution time) throughout the trials, and short-time memory by performance maintenance after a time interval (Figure 1).

Figure 1. Model of the maze, with an entrance on the left and exit on the right

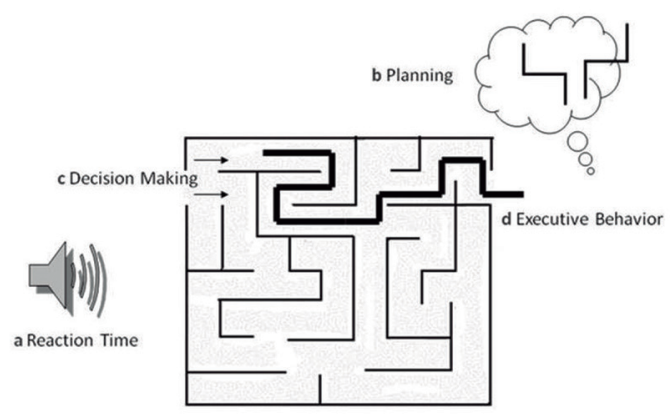

Statistical analysis

The data related to execution time on the maze test showed normal distribution of test the Kolmogorov-Smirnov. To evaluate age-related differences (young and elderly subjects) in execution time and trials on the maze tests we used ANOVA two-way repeated measures (group $\mathrm{x}$ trials). To analyze differences between the young and elderly subjects in amount of schooling and cognitive performance we used the student's t-test. The correlation between performance on the maze test and cognitive performance was analyzed by Pearson's correlation test and a multiple linear regression analysis (stepwise forward) was performed to determine the influence of age adjusted for sex, schooling and cognitive 
performance on execution time on the maze test. Data analysis was performed using SPSS 14.0 software (Statistical Package for the Social Science) at a significance level of $5 \%$.

\section{Results}

The mean age of the young individuals was 22 years $( \pm 2)$ and of the elderly subjects 67 years $( \pm 5)$. Mean schooling for the young subjects was 13 years $( \pm 1)$ and 8 years $( \pm 3)$ for the elderly individuals, confirming a significant difference between the groups $(p<0.0001)$. The scores of the Mini Mental State Examination varied from 20 to 30 , with young participants obtaining a mean score of
$28.7( \pm 1.4)$ and the elderly of $26.4( \pm$ 2.7 ), also with a significant difference between the two groups $(p<0.001)$.

After statistical analysis, a significant difference was found in execution time of the maze test between the young and the elderly, for both sexes: (mean \pm standard deviation), (men: youths $=5566$ $\pm 3249 \mathrm{~ms}$; elderly= $17267 \pm 8831 \mathrm{~ms}$; $\mathrm{p}<0.0001$ and women: youths $=5398 \pm$ $2524 \mathrm{~ms}$; elderly: $13918 \pm 6488 \mathrm{~ms} ; \mathrm{p}<$ 0.0001 ), with the same effect observed in all trials $(\mathrm{p}<0.0001)$ (Figure 2). The difference corresponded to approximately $52 \%$ for the men and $44 \%$ for women. For the young and elderly subjects of both sexes, no significant differences were found between the trials $(\mathrm{p}<0.05)$.

Figure 2. Mean execution times of the maze test for elderly men and women and young people in the 30 trials performed

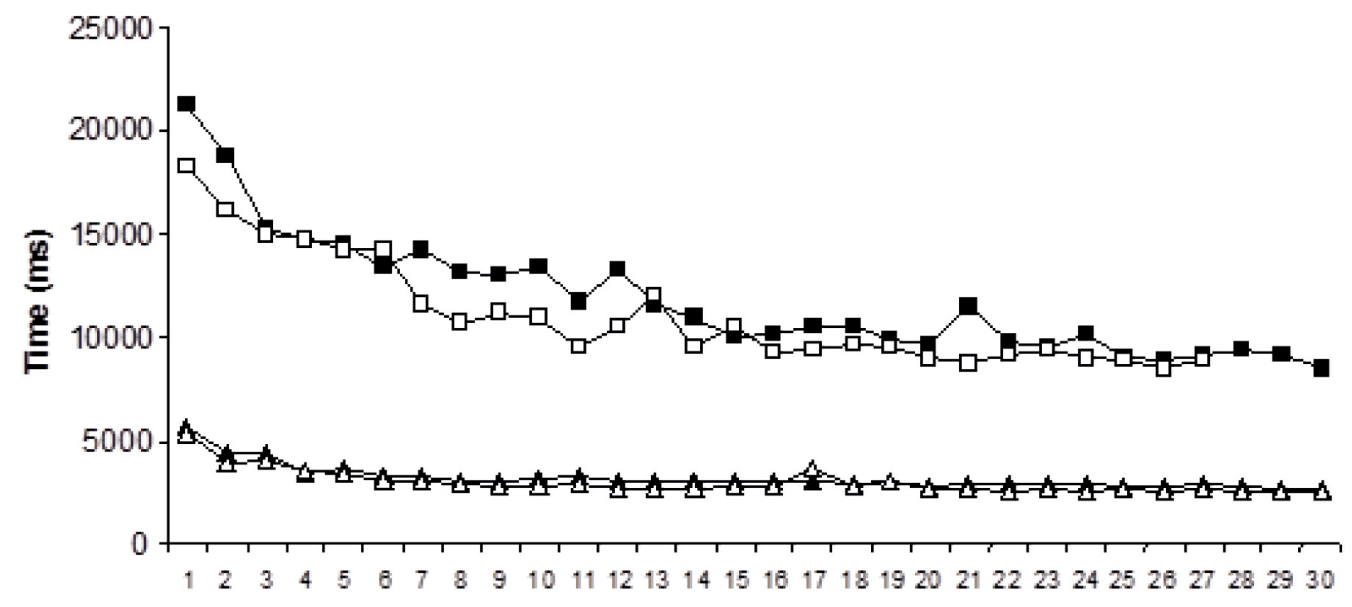

Trials

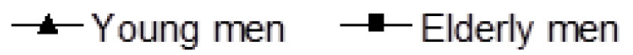

When comparing maze execution times between the 30th and 31st trials, we found significant differences between the young men $(\mathrm{p}=0.566)$ and the young $\rightarrow-$ Young women $-\square-$ Elderly women

women $(p=0.291)$; however differences were found between the elderly men $(\mathrm{p}$ $=0.020)$ and elderly women $(\mathrm{p}=0.011)$ (Figure 3). 
Figure 3. Comparison of the means and standard deviations in execution time on the 30th and 31st trials for the groups of young people and elderly individuals, both men and women

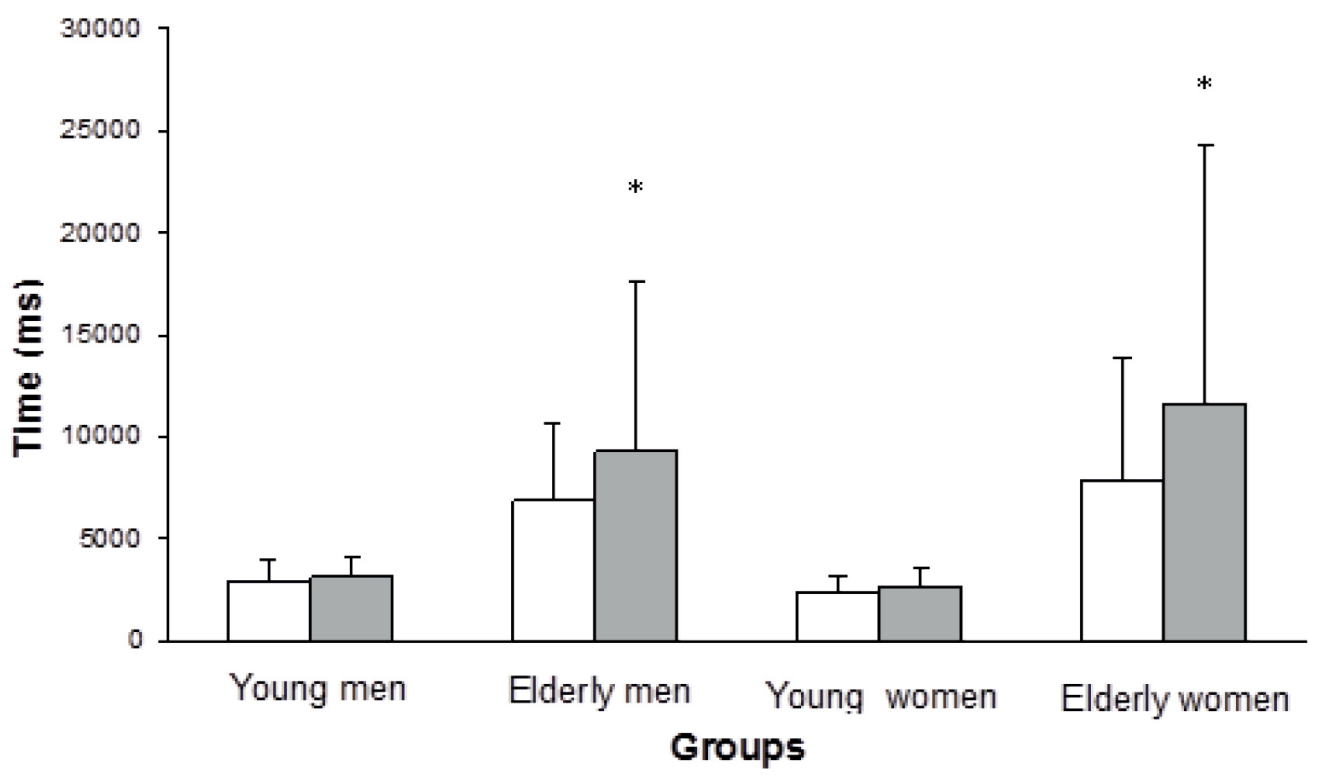

$\square 30^{\mathrm{a}}$ trial $\square 31^{\mathrm{a}}$ trial

Note: " Significant difference between the groups with $\mathrm{p}<0.05$.

A negative correlation $(\mathrm{r}=-0.324 ; \quad$ time on the maze test. According to mul$p=0.003$ ) was found between perfor- tiple linear regression analysis of the vamance on the maze test and scores on riables age, sex, schooling and cognitive the cognitive test (MMSE), confirming performance, age was the only predictive that the better the performance on the factor of performance on the maze test, cognitive test, the shorter the execution with $\mathrm{R}^{2}$ adjusted to 0.39 (Table 1).

Table 1. Multiple linear regression model (stepwise forward), considering the sex, age, schooling levels and cognitive performance as independent variables and performance on the maze test as the dependent variable

\begin{tabular}{|c|c|c|}
\hline Variable & $\beta \pm \mathrm{ET}$ & $p$ \\
\hline Sex & $0.093 \pm 0.089$ & 0.297 \\
\hline Age & $0.633 \pm 0.123$ & 0.0001 \\
\hline Schooling & $0.006 \pm 0.130$ & 0.966 \\
\hline Cognitive & $0.005 \pm 0.110$ & 0.967 \\
\hline
\end{tabular}




\section{Discussion}

Analysis of performance on the maze test showed age-related differences, with the elderly displaying longer execution times than those of the young. This result indicates that the elderly participants had difficulty in choosing a more efficient cognitive strategy for finding a solution, consequently using the longer maze paths, a decision that may be related to difficulties in executive function caused by age (PIETRZAK; COHENB; SNYDER, 2007). This slower speed, that is, longer test solution time, observed in the elderly, may be due to a greater need for cognitive demand owing to greater visual stimulus analysis and the higher requirements of the executive processes, probably to compensate the function deficits in the pre-frontal cortex observed in studies of the elderly (BRICKMAN et al., 2007).

Furthermore, it is likely that the performance observed among elderly subjects may also be related to deficits in parallel processing, suggesting an alteration in the ability to coordinate processes of different cognitive domains. According to Verwey (1996) age-related processing deficits are located in the cognitive processor and may be a result of the reduced memory capacity, slow cognitive processing, interference or simultaneity of problems for processing activities. Each of these types of potential problems has been observed in the cognitive function of the elderly. Salthouse (1996), for example, argued that the reduced processing speed associated with ageing leads to compromised cognitive function through the "limited time" mechanism, in which processing cannot be completed in adequate time and the "simultaneity" mechanism, in which advanced processing may not be available when needed for subsequent processing or execution.

Another explanation for the outcome is the possibility that the elderly have difficulty in optimizing the organization of movement sequences. Shea, Park and Braden (2006) that the elderly are unable to organize their responses into subsequences as effectively as young people do, contributing to a slower total performance in the production of sequential movements. In contrast, young people typically organize elements by understanding a sequence within a series of contiguous subsequences. This strategy reduces processing and memory demands and allows for the processing of information sequences and of articulatory commands responsible for producing the sequence elements.

Analysis of performance over the course of the trials showed no significant difference between the performance in one trial and in the following one, for either group. This finding indicates that the older group encountered no difficulty in the information acquisition stage, corroborating the study carried out by Shea, Park and Braden (2006). In an earlier study, using a similar maze to that used here, a characteristic performance curve was found, with higher scores at the start and lower at the end of the test for young individuals. However, visual clues that indicated the proper maze path had been used. Moreover, 
it was previously determined that only one path would be considered correct, a stipulation that may have influenced the variation in performance between trials (SOUZA; FRANÇA; CAMPOS, 2006). In a study conducted by Voelcker-Rehage and Willimczik (2006), they found plasticity of motor performance in elderly individuals who showed improved task performance after receiving instructions and after 6 training sessions. These subjects displayed high reserve capacity, which shows potential for learning new motor skills.

It was important to evaluate performance on the maze test after a time interval, as this examined the difficulty of the elderly in maintaining the same performance in the final attempt, which suggests a decrease in short-time memory. A similar result was found in a study that evaluated a functional motor task where performance was analyzed at the end of the training session and $48 \mathrm{~h}$ later. The older adults had lower scores than those of the younger individuals in the first analysis and a significantly greater decline in task performance after $48 \mathrm{~h}$, suggesting that the older adults did not manage to preserve a functional motor skill as well as the young adults did (TUNNEY et al., 2004). According to the literature the findings cited may be related to problems of inhibitory control of a competing motor memory or to some aspects of action representation such as the intention to move or motor predictions (BROSSEAU; POTVIN; ROULEAU, 2007), which also become progressively fragile with age (SKOURA et al., 2005).
However, in a comparative study between young adults and elderly individuals, it was proven that the elderly have great difficulty in maintaining and manipulating mental images and difficulty in spontaneously using appropriate strategic mnemonics (PALLADINO; DE BENI, 2003). It is fundamentally important to emphasize that in determining the limit between normal and pathological ageing, the characteristics of memory deficits are often considered. Recent findings suggest that the differential effect of age on perceptual-motor performance is mediated by working memory (KENNEDY; PARTRIDGE; RAZ, 2008). Working memory is a pre-frontal cortex function frequently found to be compromised in studies of patients that have specific lesions in this area. A recent study showed that working memory contributes to the recovery of the sequential order of movements (PFORDRESHER; PALMER; JUNGERS, 2007).

An interesting result in this study was the correlation between performance on the maze and cognitive (MMSE) tests, indicating the importance of the test as an auxiliary tool for detecting alterations due to age, since the MMSE is considered the gold standard instrument among screening tests. Schooling may have influenced performance on the maze test and on MMSE, since the young individuals had more schooling than the elderly subjects, although the literature shows that the differences are significant, especially between illiterate and literate persons, where more years of schooling result in better performance (LOURENÇO; VERAS, 2006). 
Since some of the elderly in the sample presented with cognitive deficit, we can also hypothesize that this, and not age, is the main cause for the compromised performance on the maze test. However, the results of this study become more reliable after regression analysis, where performance on the maze test was adjusted for age, sex, schooling and cognitive performance. It became evident that in the sample studied, age was the only predictive factor of performance on the maze test. The global coefficient obtained $\left(\mathrm{R}^{2}\right)$ indicated that $39 \%$ of the variance in test execution time can be explained by age. It is important to point out that the maze test has the advantage over MMSE of being able to monitor both cognitive and motor deficits. The number of paths and the size and complexity of the task can be changed in the maze used in this study. Moreover, during the application of the test, clues can be included, feedback can be used and more thorough analysis of the variables related to execution time and number of errors can be made. This helps in assessing the cognitive and motor processes involved in the test.

\section{Conclusion}

According to the results, the maze test was sensitive in detecting that the elderly have more difficulty in executive function, motor control and mnemonic processes. Young individuals, however, showed no alterations in learning the test. Accordingly, the maze test may contribute to the monitoring of premature cognitive and motor alterations in the elderly. New studies are being carried out to determine the diagnostic power of this test, especially with respect to chronic degenerative pathologies that lead to dementia and incapacity in the elderly.

\section{Teste de Labirinto: um instrumento para avaliar mudanças cognitiva e motora relacionadas à idade em humanos}

\section{Resumo}

Mudanças no desempenho das habilidades cognitiva e motora devido à idade avançada podem comprometer as atividades diárias. É importante determinar se o teste de labirinto pode ser sensível às alterações cognitivas ou motoras no envelhecimento normal. Dessa forma, o objetivo do estudo foi verificar as diferenças relacionadas à idade na função executiva, aprendizagem e memória de curto prazo, por meio do teste de labirinto. Participaram 80 indivíduos saudáveis, 40 jovens ( $22 \pm 2$ anos) e 40 idosos (67 \pm 5 anos), que foram submetidos a uma avaliação de saúde e cognitiva (Mini Exame do Estado Mental). Os participantes foram cronometrados para resolver 30 labirintos, e, 15 minutos mais tarde, resolvê- los novamente. Os dados foram analisados por ANOVA e regressão linear múltipla. Os idosos levaram mais tempo para resolver os labirintos, sugerindo dificuldades na função executiva; houve melhoria no desempenho nos primeiros testes, mas ocorreu um deficit na memória de curto prazo. Houve correlação entre os testes cognitivo e o de labirinto $(r=-0,32, p=0,003)$. A idade foi o único fator preditivo do desempenho. Sugere-se que o teste de labirinto pode contribuir para o acompanhamento de alterações cognitivas e motoras iniciais em idosos.

Palavras-chave: Função executiva. Aprendizagem. Memória. Cognição. Idoso.

Acknowledgements: This research was financially supported by PROAP/Capes. 


\section{References}

BECK, A. T.; STEER, R. A.; GARBIN, M. G. Psychometric properties of the Beck Depression Inventory: twenty-five years of evaluation. Clinical Psychology Review, New York, v. 8, n. 1, p. 77-100, 1988.

BRICKMAN, A. M. et al. Structural MRI covariance patterns associated with normal aging and neuropsychological functioning. Neurobiology of Aging, New York, v. 28, n. 2, p. 284-295, Feb. 2007.

BROSSEAU, J.; POTVIN, M. J.; ROULEAU, I. Aging affects motor skill learning when the task requires inhibitory control. Developmental Neuropsychology, England, v. 32, n. 1, p. 597-613, 2007.

DENNIS, N. A.; DASELAAR, S.; CABEZA, R. Effects of aging on transient and sustained successful memory encoding activity. Neurobiology of Aging, New York, v. 28, n. 11, p. 1749-1758, Nov. 2007.

FOLSTEIN, M. F.; FOLSTEIN, S. E.; MCHUGH, P. R. Mini-mental state: a practical method for grading the cognitive states of patients for clinician. Journal of Psychiatric Research, England, v. 12, n. 3, p. 189-198, 1975.

KENNEDY, K. M.; PARTRIDGE, T.; RAZ, $\mathrm{N}$. Age-related differences in acquisition of perceptual-motor skills: working memory as a mediator. Aging, Neuropsychology, and Cognition, London, v. 15, n. 2, p. 165-183, Mar. 2008.

KIRSCH, P. et al. Brain activation during mental maze solving. Neuropsychobiology, Basel, v. 54, n. 1, p. 51-58, 2006.

LOURENÇO, R. A.; VERAS, R. P. Mini-Mental State Examination: psychometric characteristics in elderly outpatients. Journal of Public Health, São Paulo, v. 40, n. 4, p. 712-719, Aug. 2006.

LOW, G.; MOLZAHN, A. E. Predictors of quality of life in old age: A cross-validation study. Research in Nursing \& Health, New York, v. 30, n. 2, p. 141-150, Apr. 2007.
MILHAM, M. P. et al. Attentional control in the aging brain: insights from an fMRI study of the Stroop task. Brain and Cognition, New York, v. 49, n. 3, p. 277-296, Aug. 2001.

OTT, B. R. et al. Maze test performance and reported driving ability in early dementia. Journal of Geriatric Psychiatry and Neurology, Thousand Oaks, v. 16, n. 3, p. 151-155, Sep. 2003.

PALLADINO, P.; DE BENI, R. When mental images are very detailed: image generation and memory permorfance as a function of age. Acta Psychologica, Amsterdam, v. 113, n. 3, p. 297-314, Jul. 2003.

PARMELEE, P. A. et al. Validation of the Cumulative Illness Rating Scale in a geriatric residential population. Journal of the American Geriatrics Society, Malden, v. 43, n. 2, p. 130-137, Feb. 1995.

PERROT, A.; BERTSCH, J. Role of age in relation between two kinds of abilities and performance in acquisition of new motor skill. Perceptual and Motor Skills, Missoula, v. 104, n. 1, p. 91-101, Feb. 2007.

PFORDRESHER, P. Q.; PALMER, C.; JUNGERS, M. K. Speed, accuracy, and serial order in sequence production. Cognitive Science, Hoboken, v. 31, n. 1, p. 63-98, Feb. 2007.

PIETRZAK, R. H.; COHENB, H.; SNYDER, P. J. Spatial learning efficiency and error monitoring in normal aging: An investigation using a novel hidden maze learning test. Archives of Clinical Neuropsychology, Oxford, v. 22 , n. 2 , p. 235-245, Feb. 2007.

SALTHOUSE T. A. Aging and measures of processing speed. Biological Psychology, Amsterdam, v. 54, n. 1-3, p. 35-54, Oct. 2000.

SALTHOUSE T. A. The processing-speed theory of adult age differences in cognition. Psychological Review, Washington, v. 130, n. 3, p. 403-428, Jul. 1996.

SCHUPF, N. et al. Decline in cognitive and functional skills increases mortality risk in nondemented elderly. Neurology, Hagerstown, v. 65 , n. 8 , p. $1218-1226$, Oct. 2005. 
SEIDLER, R. D. Aging affects motor learning but not savings at transfer of learning. Learning \& Memory, Cold Spring Harbor, v. 14, n. 1-2, p. 17-21, Jan. 2007.

SHEA, C. H.; PARK, J.; BRADEN, H. W. Age-related effects in sequential motor learning. Physical Therapy, Alexandria, v. 86, n. 4, p. 478-488, Apr. 2006.

SKOURA, X. et al. Mentally represented motor actions in normal aging. I. Age effects on the temporal features of overt and covert execution of actions. Behavioural Brain Research, Amsterdam, v. 165, n. 2, p. 229-239, Dez. 2005.

SOUZA, D. E.; FRANÇA, F. R.; CAMPOS, T. F. Maze test: instrument for analyzing the acquisition of motor skills. Brazilan Journal of Physical Therapy, São Carlos, v. 10, n. 3, p. 354-359, Sep. 2006.

TUNNEY, N. et al. Aging and motor learning of a functional motor task. Physical \& Occupational Therapy in Geriatrics, London, v. 21, n. 3, p. 1-16, 2004.

VERWEY, W. B. Buffer loading and chunking in sequential keypressing. Journal of Experimental Psychology: Human Perception and Performance, Washington, v. 22, n. 3, p. 544-562, Jun. 1996.

VOELCKER-REHAGE C.; WILLIMCZIK, K. Motor plasticity in a juggling task in older adults - a developmental study. Age Ageing, Oxford, v. 35, n. 4, p. 422-427, Jul. 2006.

WECKER, N. S. et al. Age effects on executive ability. Neuropsychology, Washington, v. 14, n. 3, p. 409-414, Jul. 2000.

YORDANOVA, J. et al. Sensorimotor slowing with ageing is mediated by a functional dysregulation of motor-generationprocesses: evidence from high-resolution event-related potentials. Brain, Oxford, v. 127, n. 2, p. 351-362, Feb. 2004. 